The Free Internet Journal

for Organic Chemistry
Paper

Arkivoc 2018, part vii, 0-0

to be inserted by editorial office

\title{
Concentrated solar radiation promoted unconventional greener approach: solvent-free benign synthesis of functionalized benzimidazoles
}

\author{
Simran Harsh, ${ }^{a}$ Mohamad Yusuf, ${ }^{b}$ Rohit Sharma, ${ }^{c}$ Yogesh Kumar, ${ }^{\text {a,d }}$ and Rupesh Kumar*a \\ a. Department of Chemical Sciences, I. K. G. Punjab Technical University, Kapurthala, Punjab, India-144603 \\ b. Department of Chemistry, Punjabi University, Patiala, Punjab, India \\ c. Department of Medicinal Chemistry, National Institute of Pharmaceutical Education and Research, Mohali, \\ Punjab, India \\ d.UNAM-National Nanotechnology Research Center, Institute of Materials Science and Nanotechnology, \\ Department of Chemistry, Bilkent University, 06800 Ankara, Turkey \\ E-mail: rupesh.manak@gmail.com
}

Received 07-10-2018

Accepted $08-27-2018$

Published on line $09-12-2018$

\section{Abstract}

Renewable concentrated solar-radiation (CSR) offered a promising en route for the development of practical, highly efficient, scalable, catalyst free and solvent-free clean process leading to the synthesis of functionalized benzimidazoles. Developed protocol has a very good substrate scope, involves mild reaction conditions and products obtained in good to excellent yields. Method presented the observations in which light alone could affect the remarkable changes with more than $85 \%$ energy saving and $75 \%$ less reaction time in listed organic transformations.

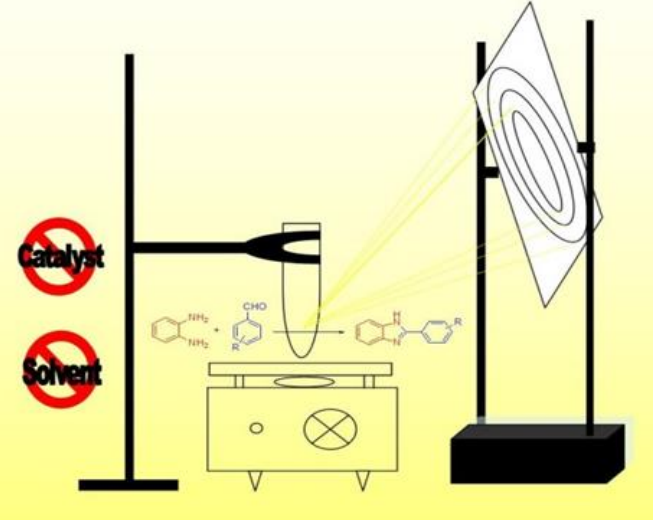

Keywords: Concentrated solar radiation, photocatalysis, solar synthesis, $\mathrm{C}-\mathrm{N}$ bond formation, benzimidazoles 
Solar light offers an inimitable, inexpensive, non-polluting, plentiful and renewable natural energy. Development of methods for efficient use of solar radiation has emerged as one of the most recent challenge. ${ }^{1-5}$ Almost every class of chemists is trying hard to realize various organic transformations exploiting natural solar light ${ }^{6-10}$ but unfortunately, despite of significant efforts, photochemical synthesis still rests in its early stage and lying far away from its effectual development. Photochemical approach for the synthesis of heterocycles has been taken up excitedly in the modern-day synthetic organic chemistry. ${ }^{11-15}$ Synthetic visible light photochemical methods ${ }^{6-10}$ are often sustainable and green as these methods represent its superiority in two ways. First; it replaces highly toxic and expensive metal catalysts and works through the conversion of reactants into its higher energy states. In this excited state, it can subsequently undergo multiple physical and chemical pathways to furnish target products and offers inherently safer chemistry. Secondly, ${ }^{16-18}$ it does not produce any chemical waste that creates disposal problems. In the given reports we have successfully procured both of these advantages.

One of the earliest and remarkable assertation was made in 1912 by Giacomo Ciamician. In his visionary lecture, he promptly anticipated the sunlight as an alternative energy source for the future. ${ }^{19} \mathrm{He}$ also speculated for a clean, environment friendly and economically viable chemical industry that could replace the conventional processes.

In photochemical protocols, one of the major concerns is the selection of a suitable light source along with the ability of molecules to absorb the light and cost effectiveness. Solar radiation is clean, renewable, safe, inexpensive and abundant source of energy that leaves no residue in harmony with the principles of green chemistry. ${ }^{18}$ The use of solar radiation is reported only for a few reactions. ${ }^{20-23}$ The need of the hour is to develop the methodologies that can effectively harness the solar energy. Concentrated solar radiation (CSR) has been proved to be very effective in a very few recent reports ${ }^{24-25}$ because of focused beam and easy handling that provided higher yield in short duration of time.

Benzimidazoles are one of the most extensively explored and acclaimed motifs for their prominent presence in huge number of potentially significant molecules ${ }^{26-32}$ that show various applications in pharmaceuticals, polymers and dyes. Some of the important drugs (Figure 1) are Omeprazole, Esomeprazole, and Lansoprazole which are commonly used in the treatment of gastroesophageal reflux disease ${ }^{33-35}$ preventing the formation of stomach acid by inhibiting the functioning of $\mathrm{H}^{+} / \mathrm{K}^{+}$-ATPase. Due to its broad spectrum of applications, substantial efforts have been made to develop the competent methods for its preparation.
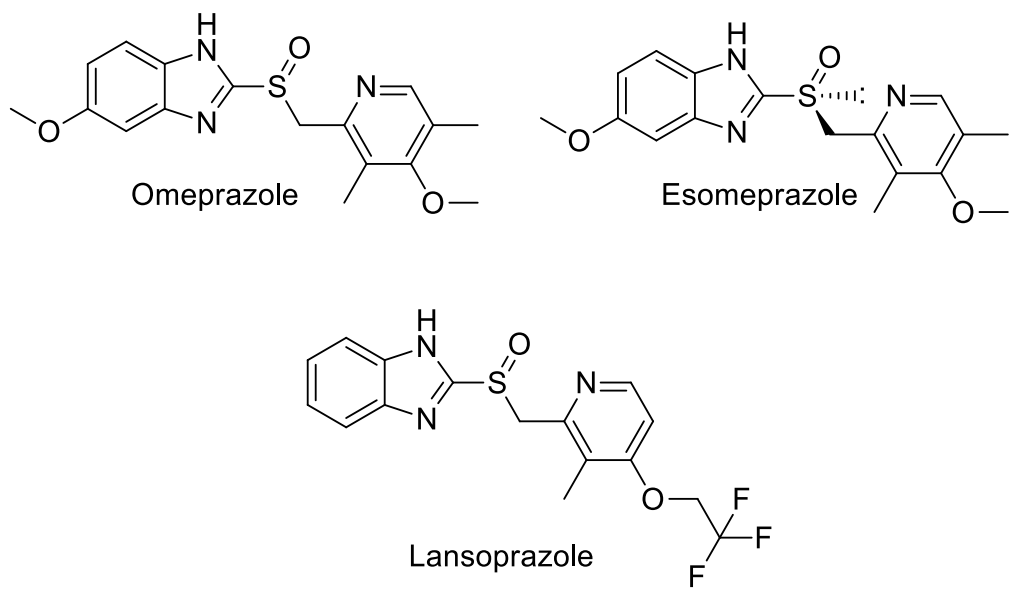

Figure 1. Some important benzimidazoles. 
Established methods involve various oxidative reagents to react the $o$-phenylenediamine with different aldehydes, carboxylic acids and its derivatives. ${ }^{36-45}$ Some of these methods have also reported the use of toxic and expensive metal catalysts, organic solvents, and long reaction time. In a latest report, ${ }^{46}$ benzimidazoles were synthesized using visible light in blue region by taking methanol as a suitable solvent. Blue light in the visible spectrum, from 400 to $450 \mathrm{~nm}$, known as high-energy visible light and have the potential for a photochemical-induced retinal injury even in the indirect exposure. ${ }^{47-49}$ To overcome such problems and make the processes viable under economic and environmental conditions, there is need to develop the competent photochemical methods stimulated by visible light wavelengths which are abundant in the solar spectrum.

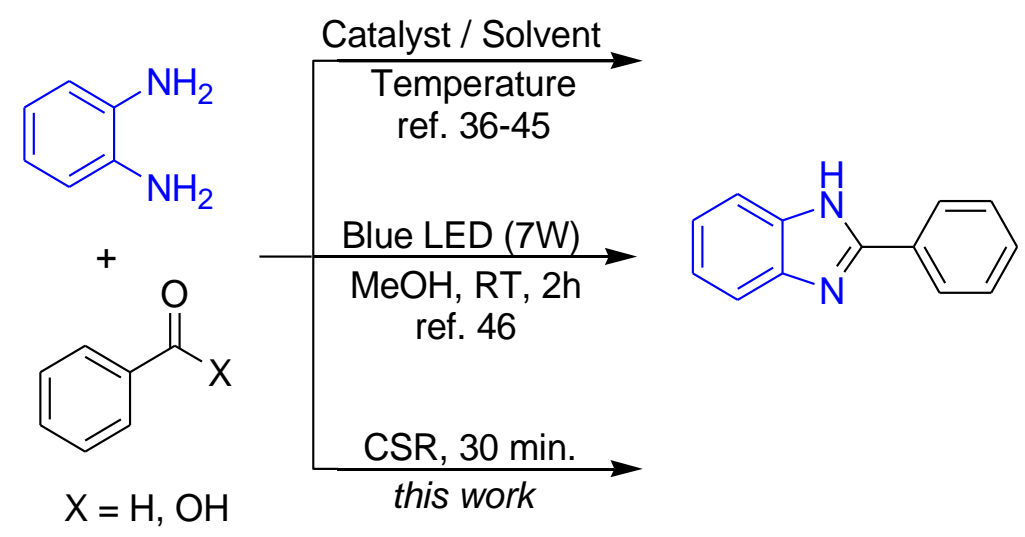

Scheme 1. Synthesis of benzimidazoles.

In the present study we developed the environmentally friendly benign approach for the formation of C-N bond and synthesized various potential derivatives of functionalized benzimidazoles using concentrated solar radiation maintaining its reproducibility.

\section{Results and Discussion}

To find an optimized protocol, we started this study with the initial reaction between o-phenylenediamine (1.0 equiv.) 1 and benzaldehyde (1.0 equiv.) $2 \mathrm{a}$ in $\mathrm{MeCN}$ in the presence of air bubbling at room temperature under Non-concentrated solar radiation (Non-CSR) for $8 \mathrm{~h}$, and only $57 \%$ of the desired product 3a (entry 1 , Table 1) was obtained. This reaction was also monitored at $2 \mathrm{~h}$ and $4 \mathrm{~h}$ interval under the same reaction conditions, but the product formation was less than $40 \%$. Subsequently we increased the reaction time upto $12 \mathrm{~h}$ that improved the reaction yield (entry 2, Table 1). Reaction was observed for another $2 \mathrm{~h}$ but that did not improve the yield significantly.

The reaction was also carried out with different solvent systems such as $\mathrm{MeOH}, \mathrm{EtOH}$, with and without the air bubbling for up to $12 \mathrm{~h}$ (entries 3-5, Table 1 ) in Non-CSR and observed, MeCN under aerobic conditions was the most suitable solvent for this protocol that improved the yield to $72 \%$. Air bubbling showed a significant improvement in yield of the desired product at room temperature. 
Table 1. Screening of the reaction conditions for the photochemical synthesis of 2-substituted benzimidazoles ${ }^{[a]}$

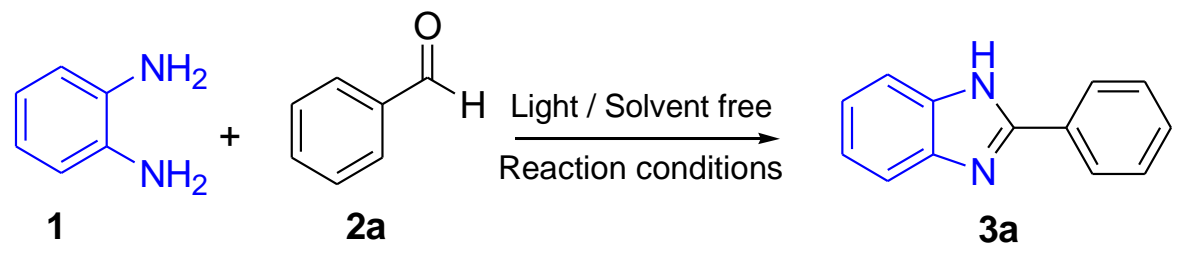

\begin{tabular}{cccccc}
\hline \multirow{2}{*}{ Entry } & \multicolumn{5}{c}{ Reaction conditions } \\
\cline { 2 - 5 } & Light & Solvent & $\mathrm{O}_{2}$ & Time & \\
\hline 1 & Non-CSR ${ }^{[\mathrm{c}]}$ & $\mathrm{MeCN}$ & $\mathrm{O}_{2}$ & $8 \mathrm{~h}$ & 57 \\
2 & Non-CSR & $\mathrm{MeCN}$ & $\mathrm{O}_{2}$ & $12 \mathrm{~h}$ & 72 \\
3 & Non-CSR & $\mathrm{MeCN}$ & - & $12 \mathrm{~h}$ & 35 \\
4 & Non-CSR & $\mathrm{MeOH}$ & $\mathrm{O}_{2}$ & $12 \mathrm{~h}$ & 60 \\
5 & Non-CSR & $\mathrm{EtOH}$ & $\mathrm{O}_{2}$ & $12 \mathrm{~h}$ & 52 \\
6 & Non-CSR & Water & $\mathrm{O}_{2}$ & $10 \mathrm{~h}$ & n.d. \\
7 & CSR (With & MeCN & $\mathrm{O}_{2}$ & $30 \mathrm{~min}$ & 70 \\
8 & coolant) & & & & \\
9 & CSR (With coolant) & Solvent-free & - & $45 \mathrm{~min}$ & 80 \\
\hline
\end{tabular}

${ }^{[a]}$ Reagents and conditions. OPD $1(1.0 \mathrm{mmol})$, aldehyde $2 \mathrm{a}(1.0 \mathrm{mmol}),{ }^{[b]}$ isolated yield after purification, ${ }^{[\mathrm{c}]}$ Non-CSR: Non-concentrated solar radiation (Broad sunlight), [d] Water is used as coolant to dissipate the heat generated during the reaction in CSR.

We also explored the reaction in water under similar conditions; however, desired product was not even detected (entry 6, Table 1). Even after getting the conditions optimized, results left us unsatisfied due to following reasons: (a) long reaction time, (b) diffused and broad sunlight for the organic reactions to carry out, (c) low chances of reproducibility due to weather conditions and, (d) uneven solar intensity throughout the day. These reasons make the procedure impractical and further prompted us to explore the practical and viable protocol. We made a reconnaissance of observations and tried to use concentrated solar radiation (CSR) for the purpose by using Fresnel lens as the concentrator. This gave us the excellent results. Initially we tried the reaction in CSR with water as a coolant and MeCN as a solvent (entry 7, table 1). CSR produces photothermal effect and generates high temperature in a very short duration of time. Coolant (water) dissipates the heat and served the purpose very well in the given procedure. The yield obtained was $70 \%$. Further, to extend our dimensions, we tried the reaction in solvent free medium under similar conditions (entry 8, table 1 ) which could provide $80 \%$ yield in $45 \mathrm{~min}$. We performed the same reaction in solvent-free medium under CSR without using any coolant that showed marvellous results. CSR excellently represented its photo-thermal effect and the reaction accomplished with $88 \%$ yield in just 30 minutes (entry 9 , table 1 ).

The reactions were performed during $12.30-3.30 \mathrm{pm}$ when the solar radiations are reportedly minimally inclined with maximum intensity. This CSR protocol could fulfil all the gaps of the previously applied non- 
Concentrated Solar Radiation (non-CSR) and proved to be practical, environment friendly and green procedure that also achieved scalability and reproducibility.

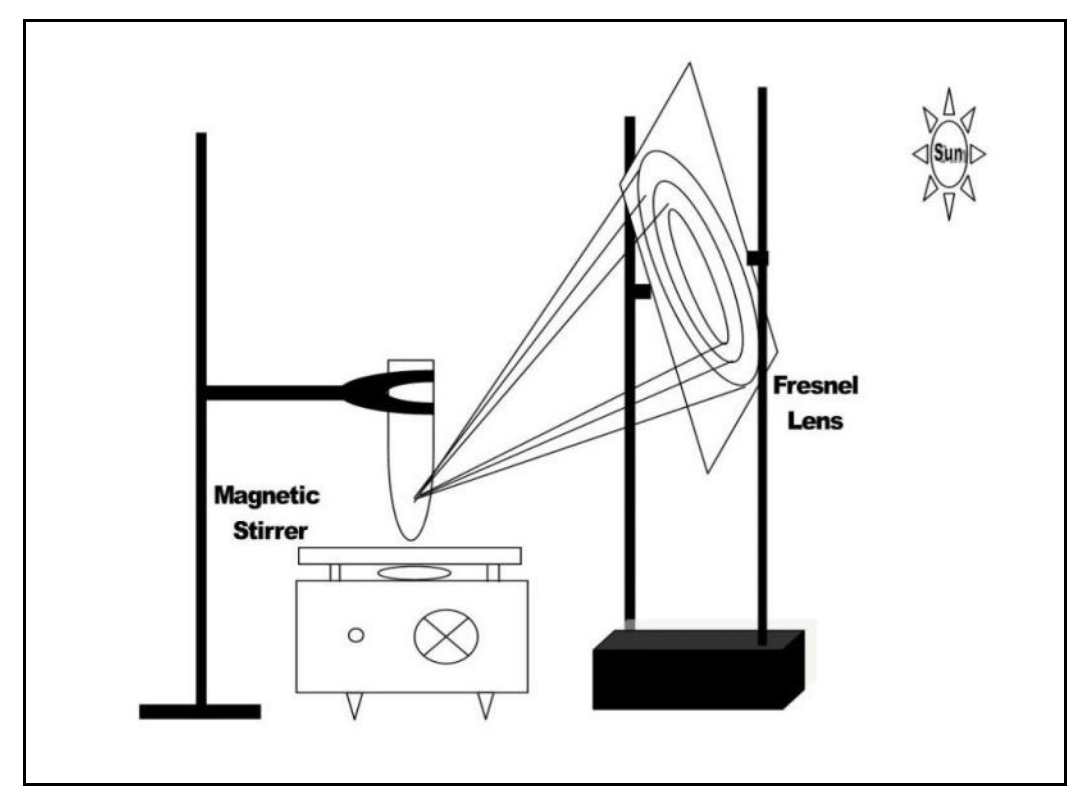

Figure 2: Schematic representation of experimental CSR Photochemical setup. ${ }^{\text {a }}$

( ${ }^{a}$ All the experiments were conducted under similar conditions at Kapurthala, Punjab, India $30^{\circ} 19^{\prime} 51.71^{\prime \prime} \mathrm{N}$, $\left.75^{\circ} 29^{\prime} 24.97^{\prime \prime} \mathrm{E} / 30.33103 \mathrm{~N}, 75.490268 \mathrm{E}\right)$

With the optimized conditions in hand, we further evaluated and explored (Table 2) the generality of the method and extended the protocol to other examples. We first studied the reaction of different substituted benzaldehydes. It is worth mentioning here that the various substituents (both electron rich and electron defficient) present on the phenyl ring presented corresponding benzimidazoles in good to excellent yields in a very short duration of time. Chloro substituted benzaldehydes provided corresponding products; $\mathbf{3 b}$ in very good yield (75\%) and $3 \mathrm{c}$ in $78 \%$ yield with lesser reaction time required. Another electron withdrawing substituted benzaldehydes gave $\mathbf{3 d}$ in $70 \%$ yield and $3 \mathrm{e}$ in $62 \%$ yield. Electron donating substituted benzaldehydes furnished desired products $\mathbf{3 f}, \mathbf{3 g} \& \mathbf{3 h}$ in very good yields (77-82\%). Further, the study was also extended to some heterocyclic carboxaldehydes and the corresponding products $\mathbf{3 j}$-3k were well isolated in very good $(81 \%)$ to excellent $(90 \%)$ yield. 31 could be isolated in $42 \%$ yield only. Similarly, cinnamaldehyde could make it through to furnish the desired products $3 \mathbf{i}$ under the optimized reaction conditions with a yield of $55 \%$ only. In the latter case, the reaction was further extended to another 15 minutes under CSR; however, it also could not make any significant affect upon the product formation and its yield. 
Table 2. Photochemical extended scope of the optimized conditions in the synthesis of 2-substituted benzimidazoles ${ }^{a, b}$

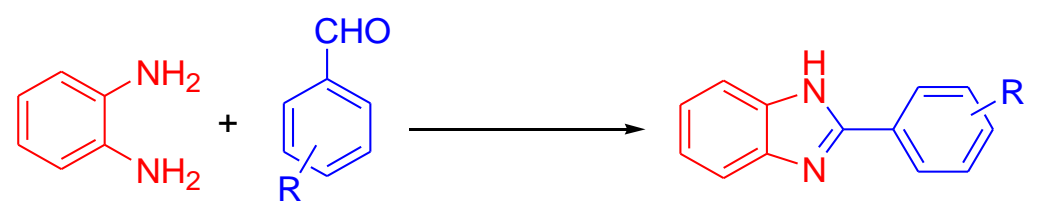<smiles>c1ccc(-c2nc3ccccc3[nH]2)cc1</smiles>

$(3 a, 88 \%)$<smiles>Brc1ccc(-c2nc3ccccc3[nH]2)cc1</smiles>

$(3 d, 70 \%)$<smiles>Cc1cccc(-c2nc3ccccc3[nH]2)c1</smiles>

$(3 g, 78 \%)$<smiles>c1csc(-c2nc3ccccc3[nH]2)c1</smiles>

(3j, 81\%)<smiles>Clc1ccccc1-c1nc2ccccc2[nH]1</smiles>

(3b, 75\%)<smiles>Cc1ccc(-c2nc3ccccc3[nH]2)cc1</smiles>

(3e, 62\%)<smiles>COc1ccc(-c2nc3ccccc3[nH]2)cc1</smiles>

(3h, 82\%)<smiles>c1ccc(-c2nc3ccccc3[nH]2)nc1</smiles>

(3k, 90\%) (3f, 77\%)

(3i, 55\%)<smiles>Clc1ccc(-c2nc3ccccc3[nH]2)cc1</smiles>

(3c, 78\%)<smiles>C(=C/c1nc2ccccc2[nH]1)\c1ccccc1</smiles><smiles>c1coc(-c2nc3ccccc3[nH]2)c1</smiles>

(3I, 42\%)

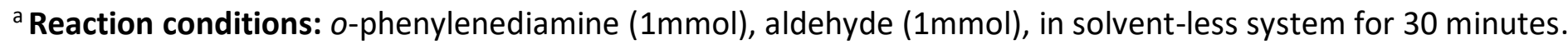
${ }^{\mathrm{b}}$ Isolated yields are given in parenthesis.

\section{Energy calculations}

The energy requirements from external power supply for the synthesis of 2-substituted benzimidazoles using the visible blue light and CSR are calculated. The energy consumed for the synthesis of 2-substituted benzimidazoles is the total energy consumed $(\mathrm{kJ})$ per unit weight of the total amount of the reactants used ( $\mathrm{g}$ ). The reaction time to synthesise 2-substituted benzimidazoles was $120 \mathrm{~min}$ for visible blue light method and 30 min for the CSR. The amount of energy required to synthesize the 2-substituted benzimidazoles per gram is $17.325 \mathrm{~kJ} / \mathrm{g}$ and $132.3 \mathrm{~kJ} / \mathrm{g}$ for CSR and visible light method respectively. Thus, CSR protocol proved to be energy efficient with more than $85 \%$ energy saving and $75 \%$ reduction in time.

Energy consumed in visible light (Blue LED 7W). Total Energy consumed from the external power source in this process $=$ Energy consumed by blue LED in $2 \mathrm{~h}$ (120 min.) + Energy consumed by Magnetic stirrer for 120 $\min$. 
Total energy consumed from external power source by the 7W LED in 120 min. process $=$ Power input in LED $\times$ Time required for completion of the reaction.

$=7(\mathrm{~J} / \mathrm{s}) \times 120 \times 60 \mathrm{~s}=50400 \mathrm{~J}=50.4 \mathrm{~kJ}$

Voltage input in magnetic stirrer (Model $2 \mathrm{~L}$ Remi, India) $=220 \mathrm{~V}$.

Current measured using a digital multi-meter $=35 \mathrm{~mA}=35 \times 10^{-3} \mathrm{~A}$.

Power input in magnetic stirrer $=$ Voltage input $\times$ Current measured $=220(\mathrm{~V}) \times 35 \times 10^{-3}(\mathrm{~A})=7.7 \mathrm{~W}(\mathrm{~J} / \mathrm{s})$.

Total energy consumed by the stirrer over $120 \mathrm{~min}$. process $=$ Power input in magnetic stirrer $\times$ Time required for completion of the reaction.

$=7.7(\mathrm{~J} / \mathrm{s}) \times 120 \times 60 \mathrm{~s}=55440 \mathrm{~J}=55.440 \mathrm{~kJ}$

Total Energy consumed in the process $=50.4(\mathrm{~kJ})+55.44(\mathrm{~kJ})=105.84 \mathrm{~kJ}$

Quantity of material processed = Quantity of (o-phenylenediamine + benzaldehyde) in $\mathrm{g} .=0.4+0.4=0.8 \mathrm{~g}$.

The amount of energy consumed from external power source to process material per gram = Net energy consumed during Stirring/Quantity of reactants).

$$
=105.84(\mathrm{~kJ}) / 0.8(\mathrm{~g})=132.3 \mathrm{~kJ} / \mathrm{g}
$$

Energy consumed in concentrated solar radiation (CSR). This work: Total Energy consumed from external power supply in the process = Energy consumed by Magnetic stirrer in $30 \mathrm{~min}$.

Energy consumed by the stirrer in $30 \mathrm{~min}$. process $=$ Power input in magnetic stirrer $\times$ Time required for completion of the reaction.

$$
=7.7(\mathrm{~J} / \mathrm{s}) \times 30 \mathrm{~min} . \times 60 \mathrm{~s}=13860 \mathrm{~J}=13.860 \mathrm{~kJ}
$$

Quantity of material processed = Quantity of (o-phenylenediamine + benzaldehyde) in g. $=0.4+0.4=0.8 \mathrm{~g}$.

The amount of energy consumed during the process per gram = Net energy consumed during Stirring/Quantity of material processed).

$$
=13.860(\mathrm{~kJ}) / 0.8(\mathrm{~g})=17.325 \mathrm{~kJ} / \mathrm{g}
$$

Energy saving. The amount of energy saved during the process $=$ Net energy consumed from the external power supply for processing of material using blue LED method for $2 \mathrm{~h}$ - Energy consumed from external power supply for processing of material using CSR $=(132.3-17.325) \mathrm{kJ} / \mathrm{g}=114.97 \mathrm{~kJ} / \mathrm{g}$

Energy saved during the process $(\%)=$ (the amount of energy saved during the process/Net energy supplied for processing of material using conventional method) $\times 100$

$$
=(114.97 / 132.3) \times 100=86.90 \%
$$

\section{Conclusions}

This protocol presents an expedient, energy efficient, sustainable, atom economical, and eco-friendly unprecedented method for the synthesis of functionalized benzimidazoles. A wide range of aldehydes were studied to this new synthetic methodology to afford functionalized benzimidazoles with good efficiencies under very benevolent reaction conditions. In addition, solar radiation, no extra reagents and operational simplicity prove it as a novel and innovative striking mode of the present-day organic synthesis. This method is also proved to be remarkable energy saving with tremendously lower reaction time. 


\section{Experimental Section}

General. Oxygen- and moisture-sensitive reactions were carried out under nitrogen atmosphere. Solvents were purified and dried by standard methods prior to use. All commercially available reagents and solvents (purchased from Aldrich, Merck, Spectrochem, Acros) were used without further purification unless otherwise noted. Analytical thin layer chromatography (TLC) was conducted on Merck Kieselgel 60 F254. Column chromatography was performed on silica gel (100-200 mesh). Melting points were determined in capillary tubes using a Mel-Temp apparatus and are not corrected. Infrared spectra were obtained as films on $\mathrm{KBr}$ salt plates except where otherwise specified, using a Perkin Elmer FT-IR spectrometer. ${ }^{1} \mathrm{H}$ NMR spectra were obtained with $\mathrm{CDCl}_{3}$ at $500 \mathrm{MHz}$, using Bruker spectrometers (residual chloroform referenced to $7.26 \mathrm{ppm}$ ) or DMSO- $d_{6}$ (residual DMSO referenced to $2.50 \mathrm{ppm}$ and residual water in DMSO- $d_{6}$ appearing at $3.34 \mathrm{ppm}$ ). Chemical shift values are expressed as parts per million downfield from TMS and $J$ values are in hertz. Splitting patterns are indicated as s: singlet, $d$ : doublet, t: triplet, m: multiplet, dd: double doublet, ddd: doublet of a doublet of a doublet, and br: broad peak. ${ }^{13} \mathrm{C}$ NMR spectra were recorded with $\mathrm{CDCl}_{3}$ at $75 \mathrm{MHz}$, using Bruker spectrometers (residual chloroform referenced to $77.0 \mathrm{ppm}$ ) or DMSO- $d_{6}$ (residual DMSO referenced to 39.5 ppm). HRMS were recorded on Bruker high resolution spectrometer (BrukermicrOTOF QII).

General procedure for synthesis of compound 2-aryl-1H-benzimidazoles $\mathbf{3}$. In a typical experiment, a mixture of aromatic aldehyde 2 (1 $\mathrm{mmol})$ and $o$-phenylenediamine (1) $(1 \mathrm{mmol})$ was taken in a test tube. The reaction mixture was stirred on magnetic stirrer in concentrated solar radiation (CSR) for 20-30 minutes and monitored by TLC. On completion of the reaction, the reaction mixture was cooled to room temperature. The 2 -aryl-1Hbenzimidazoles $\mathbf{3}$ were isolated by using column chromatography over Silica gel using hexane-EtOAc as eluent as and when required.

2-Phenyl-1H-benzo[d]imidazole (3a). Yield 88\%; light brown solid; mp 293-294 ${ }^{\circ} \mathrm{C}$; ${ }^{1} \mathrm{H} \mathrm{NMR}(500 \mathrm{MHz}$, DMSO$\left.d_{6}\right) \delta 13.01(\mathrm{br} \mathrm{s}, 1 \mathrm{H}), 8.19(\mathrm{~d}, J 9.0 \mathrm{~Hz}, 2 \mathrm{H}), 7.69(\mathrm{~d}, J 7.5 \mathrm{~Hz}, 1 \mathrm{H}), 7.53(\mathrm{~m}, 4 \mathrm{H}), 7.18(\mathrm{~m}, 2 \mathrm{H}) ;{ }^{13} \mathrm{C}$ NMR (DMSO$\left.d_{6}, 75 \mathrm{~Hz}\right): \delta 112.1,118.8,122.9,123.7,126.8,128.7,129.1,131.0,135.2,144.9,151.4$. MS $m / z 195(\mathrm{M}+1)$; Anal. Calc. for $\mathrm{C}_{13} \mathrm{H}_{10} \mathrm{~N}_{2}$ : C, 80.39; $\mathrm{H}, 5.19 ; \mathrm{N}, 14.42$; found: $\mathrm{C}, 80.43 ; \mathrm{H}, 5.22 ; \mathrm{N}, 14.33$.

2-(2-Chlorophenyl)-1H-benzo[d]imidazole (3b). Yield 75\%; Off white solid; mp 230-232 ${ }^{\circ} \mathrm{C}^{1} \mathrm{H} \mathrm{NMR}(500 \mathrm{MHz}$, DMSO-d 6 ) $\delta 12.79$ (br s, $1 \mathrm{H}), 7.91(\mathrm{dd}, 1 \mathrm{H}), 7.66(\mathrm{dd}, J 8 \mathrm{~Hz}, 1 \mathrm{H}), 7.50-7.56(\mathrm{~m}, 1 \mathrm{H}), 7.26-7.23(\mathrm{~m}, 5 \mathrm{H}) \mathrm{ppm} ;{ }^{13} \mathrm{C}$ NMR (DMSO- $\left.d_{6}, 75 \mathrm{~Hz}\right): \delta$ 149.5, 132.5, 132.1, 131.7, 130.8, 130.4, 127.9, 122.1, 118.9, 111.8, 111.5 ppm; MS $\mathrm{m} / \mathrm{z} 229(\mathrm{M}+1)$; Anal. Calc. for $\mathrm{C}_{13} \mathrm{H}_{9} \mathrm{ClN}_{2}$ : C, 68.28; $\mathrm{H}, 3.97 ; \mathrm{N}, 12.25 ;$ found: $\mathrm{C}, 68.27 ; \mathrm{H}, 3.99 ; \mathrm{N}, 12.21$.

2-(4-Chlorophenyl)-1H-benzo[d]imidazole (3c). Yield 78\%; pale yellow solid; ${ }^{1} \mathrm{H}$ NMR (500 MHz, DMSO- $\left.d_{6}\right) \delta$ 12.96 (br s, 1H), 8.20 (d, J $8.5 \mathrm{~Hz}, 2 \mathrm{H}), 7.68$ (d, J $7.5 \mathrm{~Hz}, 1 \mathrm{H}), 7.61$ (d, J $9.5 \mathrm{~Hz}, 2 \mathrm{H}), 7.53(\mathrm{~m}, 1 \mathrm{H}), 7.23(\mathrm{~m}, 2 \mathrm{H})$; ${ }^{13} \mathrm{C}$ NMR (DMSO- $\left.d_{6}, 75 \mathrm{~Hz}\right): \delta 111.7,118.6,121.5,123.0 .128 .5,128.7,129.1,134.8,135.2,143.2,150.2$. MS $\mathrm{m} / \mathrm{z} 229$ (M+1); Anal. Calc. for $\mathrm{C}_{13} \mathrm{H}_{9} \mathrm{ClN}_{2}$ : C, 68.28; $\mathrm{H}, 3.97 ; \mathrm{N}, 12.25 ;$ found: $\mathrm{C}, 68.30 ; \mathrm{H}, 3.98 ; \mathrm{N}, 12.20$.

2-(4-Bromophenyl)-1H-benzo[d]imidazole (3d). Yield 70\%; pale yellow solid; mp 254-255 ${ }^{\circ} \mathrm{C} ;{ }^{1} \mathrm{H}$ NMR $(500$ $\left.\mathrm{MHz}, \mathrm{DMSO}-d_{6}\right) \delta 13.05$ (br s, $\left.1 \mathrm{H}\right), 8.12(\mathrm{~m}, 2 \mathrm{H}), 7.78(\mathrm{~d}, J 8.0 \mathrm{~Hz}, 2 \mathrm{H}), 7.67(\mathrm{~s}, 1 \mathrm{H}), 7.55(\mathrm{~s}, 1 \mathrm{H}), 7.21(\mathrm{~s}, 2 \mathrm{H}) ;{ }^{13} \mathrm{C}$ NMR (DMSO- $\left.d_{6}, 75 \mathrm{~Hz}\right): \delta 111.8,188.8,122.3,123.6,123.8,128.5,129.0,129.9,135.2,143.5,150.1$. MS m/z $273(\mathrm{M}+1)$; Anal. Calc. for $\mathrm{C}_{13} \mathrm{H}_{9} \mathrm{BrN}_{2}$ : C, 57.17; H, 3.32; N, 10.26; found: C, 57.19; H, 3.35; N, 10.22.

2-(4-Nitrophenyl)-1H-benzo[d]imidazole (3e). Yield 62\%; pale yellow solid; ${ }^{1} \mathrm{H}$ NMR (500 MHz, DMSO- $\left.d_{6}\right) \delta$ 13.22 (br s, $1 \mathrm{H}), 8.38(\mathrm{~m}, 4 \mathrm{H}), 7.67(\mathrm{~s}, 2 \mathrm{H}), 7.27(\mathrm{~s}, 2 \mathrm{H}) ;{ }^{13} \mathrm{C} \mathrm{NMR}$ (DMSO-d, $\left.75 \mathrm{~Hz}\right): \delta 115.1,122.8,124.5,124.6$, 127.8, 127.9, 134.5, 136.2, 147.7, 149.3, 150.1. MS m/z $240(\mathrm{M}+1)$; Anal. Calc. for $\mathrm{C}_{13} \mathrm{H}_{9} \mathrm{~N}_{3} \mathrm{O}_{2}: \mathrm{C}, 65.27 ; \mathrm{H}, 3.79$; N, 17.56; found: C, $65.35 ; \mathrm{H}, 3.83 ; \mathrm{N}, 17.55$. 
2-(p-Tolyl)-1H-benzo[d]imidazole (3f). Yield 77\%; white solid; mp 275-276 ${ }^{\circ} \mathrm{C} ;{ }^{1} \mathrm{H}$ NMR (500 MHz, DMSO- $\left.d_{6}\right) \delta$ 12.85 (br s, 1H), 8.06 (d, J $7.5 \mathrm{~Hz}, 2 \mathrm{H}), 7.63(\mathrm{~s}, 1 \mathrm{H}), 7.52(\mathrm{~s}, 1 \mathrm{H}), 7.33(\mathrm{~m}, 2 \mathrm{H}), 7.19(\mathrm{~s}, 2 \mathrm{H}), 2.37(\mathrm{~s}, 3 \mathrm{H}) ;{ }^{13} \mathrm{C} \mathrm{NMR}$ (DMSO- $\left.d_{6}, 75 \mathrm{~Hz}\right): \delta 21.1,111.3,118.7,121.5,122.4,126.6,127.4,129.5,135.1,139.8,143.8,151.1 . \mathrm{MS} \mathrm{m} / \mathrm{z}$ 209 (M+1); Anal. Calc. for $\mathrm{C}_{14} \mathrm{H}_{12} \mathrm{~N}_{2}$ : C, 80.74; H, 5.81; N, 13.45; found: C, 80.80; H, 5.83; N, 13.44.

2-(m-Tolyl)-1H-benzo[d]imidazole (3g). Yield 78\%; white solid; mp 232-233 ${ }^{\circ} \mathrm{C} ;{ }^{1} \mathrm{H}$ NMR (500 MHz, DMSO- $\left.d_{6}\right) \delta$ $12.88(\mathrm{br} \mathrm{s}, 1 \mathrm{H}), 8.03(\mathrm{~s}, 1 \mathrm{H}), 7.97(\mathrm{~d}, J 7.5 \mathrm{~Hz}, 1 \mathrm{H}), 7.55(\mathrm{~m}, 3 \mathrm{H}), 7.31(\mathrm{~d}, J 7.0 \mathrm{~Hz}, 1 \mathrm{H}), 7.18(\mathrm{~m}, 2 \mathrm{H}), 2.40(\mathrm{~s}$, $3 \mathrm{H}) ;{ }^{13} \mathrm{C}$ NMR (DMSO- $d_{6}, 75 \mathrm{~Hz}$ ): $\delta 21.5,111.7,119.3,122.2,122.8,124.0,127.5,129.3,130.2,130.8,135.5$, 138.6, 144.2, 151.9. MS m/z 209 (M+1); Anal. Calc. for $\mathrm{C}_{14} \mathrm{H}_{12} \mathrm{~N}_{2}$ : C, 80.74; $\mathrm{H}, 5.81 ; \mathrm{N}, 13.45$; found: $\mathrm{C}, 80.76 ; \mathrm{H}$, $5.88 ; \mathrm{N}, 13.41$.

2-(4-Methoxyphenyl)-1H-benzo[d]imidazole (3h). Yield 82\%; pale yellow solid; ${ }^{1} \mathrm{H}$ NMR (500 MHz, DMSO- $\left.d_{6}\right) \delta$ 12.87 (br s, $1 \mathrm{H}), 8.10$ (d, J $7.5 \mathrm{~Hz}, 2 \mathrm{H}), 7.53(\mathrm{~s}, 2 \mathrm{H}), 7.12(\mathrm{~m}, 4 \mathrm{H}), 3.86(\mathrm{~s}, 3 \mathrm{H}) ;{ }^{13} \mathrm{C} \mathrm{NMR}$ (DMSO- $\left.d_{6}, 75 \mathrm{~Hz}\right): \delta 55.5$, 111.9, 114.1, 114.8, 121.1, 122.4, 128.5, 151.8, 164.9. MS m/z 225 (M+1); Anal. Calc. for $\mathrm{C}_{14} \mathrm{H}_{12} \mathrm{~N}_{2} \mathrm{O}: \mathrm{C}, 74.98$; H, 5.39; N, 12.49; found: C, 75.02; H, 5.44; N, 12.47 .

(E)-2-Styryl-1H-benzo[d]imidazole (3i). Yield 55\%; pale yellow solid; ${ }^{1} \mathrm{H}$ NMR (500 MHz, DMSO- $\left.d_{6}\right) \delta 12.99(\mathrm{br}$ $\mathrm{s}, 1 \mathrm{H}), 7.75(\mathrm{~m}, 2 \mathrm{H}), 7.36(\mathrm{~m}, 6 \mathrm{H}), 7.18(\mathrm{~m}, 2 \mathrm{H}), 7.05(\mathrm{~d}, J 7.5 \mathrm{~Hz}, 1 \mathrm{H}) ;{ }^{13} \mathrm{C}$ NMR (DMSO- $\left.d_{6}, 75 \mathrm{~Hz}\right): \delta 111.7$, 121.3, 122.1, 127.3, 128.3, 128.7, 133.4, 37.5, 152.9. MS m/z $221(\mathrm{M}+1)$; Anal. Calc. for $\mathrm{C}_{15} \mathrm{H}_{12} \mathrm{~N}_{2}: \mathrm{C}, 81.79 ; \mathrm{H}$, $5.49 ; \mathrm{N}, 12.72$; found: $\mathrm{C}, 81.85 ; \mathrm{H}, 5.51 ; \mathrm{N}, 12.64$.

2-(Thiophen-2-yl)-1H-benzo[d]imidazole (3j). Yield 81\%; pale yellow solid; mp 342-344 ${ }^{\circ} \mathrm{C} ;{ }^{1} \mathrm{H} \mathrm{NMR}(500 \mathrm{MHz}$, DMSO-d $)) \delta 12.99$ (br s, 1H), $7.83(\mathrm{~d}, J 4.0 \mathrm{~Hz}, 1 \mathrm{H}), 7.71$ (d, J $5.5 \mathrm{~Hz}, 1 \mathrm{H}), 7.60(\mathrm{~s}, 1 \mathrm{H}), 7.51(\mathrm{~s}, 1 \mathrm{H}), 7.22(\mathrm{~m}, 3 \mathrm{H})$; ${ }^{13} \mathrm{C}$ NMR (DMSO- $\left.d_{6}, 75 \mathrm{~Hz}\right): \delta 111.3,118.9,121.2,122.9,127.6,128.7,129.6,134.0,135.1,143.3,147.7 . \mathrm{MS}$ $\mathrm{m} / \mathrm{z} 201(\mathrm{M}+1)$; Anal. Calc. for $\mathrm{C}_{11} \mathrm{H}_{8} \mathrm{~N}_{2} \mathrm{~S}: \mathrm{C}, 65.97 ; \mathrm{H}, 4.03 ; \mathrm{N}, 13.99 ;$ found: $\mathrm{C}, 65.99 ; \mathrm{H}, 4.10 ; \mathrm{N}, 13.91$.

2-(Pyridin-2-yl)-1H-benzo[d]imidazole (3k). Yield 90\%; pale yellow solid; ${ }^{1} \mathrm{H}$ NMR (500 MHz, DMSO-d $) \delta 13.10$ (br s, 1H), $8.73(\mathrm{~m}, 1 \mathrm{H}), 8.05(\mathrm{~d}, J 7.5 \mathrm{~Hz}, 1 \mathrm{H}), 7.79(\mathrm{~m}, 3 \mathrm{H}), 7.73(\mathrm{~m}, 1 \mathrm{H}), 7.20(\mathrm{~m}, 2 \mathrm{H}) ;{ }^{13} \mathrm{C}$ NMR (DMSO-d $d_{6}$ $75 \mathrm{~Hz}): \delta 112.0,119.5,122.7,123.4,135.1,137.6,144.3,148.6,151.1 . \mathrm{MS} \mathrm{m} / \mathrm{z} 196$ (M+1); Anal. Calc. for $\mathrm{C}_{12} \mathrm{H}_{9} \mathrm{~N}_{3}$ : C, 73.83; $\mathrm{H}, 4.65 ; \mathrm{N}, 21.52$; found: $\mathrm{C}, 73.88 ; \mathrm{H}, 4.67 ; \mathrm{N}, 21.50$.

2-(Furan-2-yl)-1H-benzo[d]imidazole (3l). Yield 42\%; pale yellow solid; ${ }^{1} \mathrm{H}$ NMR (500 MHz, DMSO- $\left.d_{6}\right) \delta 12.88$ (br s, 1H), $7.87(\mathrm{~m}, 2 \mathrm{H}), 7.51(\mathrm{~m}, 2 \mathrm{H}), 7.05(\mathrm{~d}, J 3.5 \mathrm{~Hz}, 1 \mathrm{H}), 6.08(\mathrm{~m}, 2 \mathrm{H}) ;{ }^{13} \mathrm{C}$ NMR (DMSO-d, $\left.75 \mathrm{~Hz}\right): \delta 110.1$, 111.0, 113.2, 121.7, 137.3, 137.9, 151.1, 155.9. MS m/z $185(\mathrm{M}+1)$; Anal. Calc. for $\mathrm{C}_{11} \mathrm{H}_{8} \mathrm{~N}_{2} \mathrm{O}: \mathrm{C}, 71.73 ; \mathrm{H}, 4.38$; N, 15.21; found: C, 71.74; H, 4.44; N, 15.15 .

\section{Acknowledgments}

The support and research facilities provided by I. K. Gujral Punjab Technical University (PTU), Kapurthala are highly acknowledged.

\section{Supplementary Material}

Copies of ${ }^{1} \mathrm{H}$ and ${ }^{13} \mathrm{C}$ NMR spectra of representative compounds are available in the supplementary material file. 


\section{References}

1. Lewis, N. S. Science 2007, 315, 798. https://doi.org/10.1126/science.1137014

2. Morton, O. Nature 2006, 443, 19. https://doi.org/10.1038/443019a

3. Albini, A.; Fagnoni, M. Green Chem. 2004, 6, 1. https://doi.org/10.1039/b309592d

4. Albini, A.; Fagnoni, M. ChemSusChem 2008, 1, 63. https://doi.org/10.1002/cssc.200700015

5. Roth, H. D. Angew. Chem. Int. Ed. 1989, 28, 1193. https://doi.org/10.1002/anie.198911931

6. Oelgemöller, M. Chem. Rev. 2016, 116 (17), 9664. https://doi.org/10.1021/acs.chemrev.5b00720

7. Konig, B. Eur. J. Org. Chem. 2017, 15, 1979. https://doi.org/10.1002/ejoc.201700420

8. Chen, J. -R.; Hu, X. -Q.; Lu, L. -Q.; Xiao, W. -J. Acc. Chem. Res. 2016, 49(9), 1911. https://doi.org/ 10.1021/acs.accounts.6b00254

9. Schultz, D. M.; Yoon, T. P. Science 2014, 343, 1239176. https://doi.org/10.1126/science.1239176

10. Narayanam, J. M. R.; Stephenson, C. R. J. Chem. Soc. Rev. 2011, 40, 102. https://doi.org/10.1039/B913880N

11. Brimioulle, R.; Lenhart, D.; Maturi, M.; Bach, T. Angew. Chem. Int. Ed. 2015, 54 (13), 3872. https://doi.org/10.1002/anie.201411409

12. De Keukeleire, D.; He, S. L. Chem. Rev. 1993, 93 (1), 359. https://doi.org/10.1021/cr00017a017

13. Fagnoni, M.; Dondi, D.; Ravelli, D.; Albini, A. Chem. Rev. 2007, 107 (6), 2725. https://doi.org/10.1021/cr068352x

14. Hoffmann, N. Chem. Rev. 2008, 108 (3), 1052. https://doi.org/10.1021/cr0680336

15. Hoffmann, N. J. Phys. Org. Chem. 2015, 28 (2), 121.

https://doi.org/10.1002/poc.3370

16. Protti, S.; Fagnoni, M. Photochem. Photobiol. Sci. 2009, 8, 1499. https://doi.org/10.1039/b909128a

17. Ravelli, D.; Protti, S.; Fagnoni, M. in Applications of Visible and Solar Light in Organic Synthesis, Ch. 6 Applied Photochemistry: When light meets molecules Bergamini, G.; Silvi, S. Eds. Springer: Switzerland, 2016, pp 281-342.

18. Albini, A.; Fagnoni, M. Green Chem. 2004, 6, 1.

https://doi.org/10.1039/b309592d

19. Ciamician, G. Science 1912, 36. 385.

https://doi.org/10.1126/science.36.926.385

20. Amin, S.; Barnes, A.; Buckner, C.; Jones, J.; Monroe, M.; Nurmomade, L.; Pinto, T.; Starkey, S.; Agee, B.M.; Crouse, D.J.,, Swartling, D.J. J. Chem. Educ. 2015, 92, 767. https://doi.org/10.1021/ed500850c 
21. Oelgemiller, M.; Healy, N.; de Oliveira, L.; Jung, C.; Mattay, J. Green Chem. 2006, 8, 831. https://doi.org/10.1039/B605906F

22. Covell, C.; Gilbert, A.; Richter, C.; J. Chem. Res. Synopses 1998, 316.

23. Mekheimer, R.A.; Ameen, M.A.; Sadek, K.U. Chinese Chem. Lett. 2008, 19, 788. https://doi.org/10.1016/j.cclet.2008.04.041

24. Deshpande, S.; Gadilohar, B.; Shinde, Y.; Pinjari, D.; Pandit, A.; Shankarling, G. Sol. Energy, 2015, 113, 332. https://doi.org/10.1016/j.solener.2015.01.008

25. Jadhav, N.; Pandit, A.; Pinjari, D. Sol. Energy 2017, 147, 232.

https://doi.org/10.1016/i.solener.2017.03.047

26. Yadav, G.; Ganguly, S. Eur. J. Med. Chem. 2015, 97, 419.

https://doi.org/10.1016/i.ejmech.2014.11.053

27. Bansal, Y.; Silakari, O. Bioorg. Med. Chem. 2012, 20, 6208.

https://doi.org/10.1016/j.bmc.2012.09.013

28. Porcari, A. R.; Devivar, R. V.; Kucera, L. S.; Drach, J. C.; Townsend, L. B. J. Med. Chem. 1998, 41, 1252. https://doi.org/10.1021/jm970559i

29. Keri, R. S.; Hiremathad, A.; Budagumpi, S.; Nagaraja, B. M. Chem. Biol. Drug Des. 2015, 86, 19. https://doi.org/10.1111/cbdd.12462

30. Scott, L. J.; Dunn, C. J.; Mallarkey, G.; Sharpe, M. Drugs 2002, 62, 1503.

https://doi.org/10.2165/00003495-200262100-00006

31. Al Muhaimeed, H. J. Int. Med. Res. 1997, 25, 175. https://doi.org/10.1177/030006059702500401

32. Nakano, H.; Inoue, T.; Kawasaki, N.; Miyataka, H.; Matsumoto, H.; Taguchi, T.; Inagaki, N.; Nagai, H.; Satoh, T. Bioorg. Med. Chem. 2000, 8, 373. https://doi.org/10.1016/S0968-0896(99)00291-6

33. EINezhawy, A. O.; Biuomy, A. R.; Hassan, F. S.; Ismaiel, A. K.; Omar, H. Bioorg. Med. Chem. 2013, $21,1661$. https://doi.org/10.1016/j.bmc.2013.01.070

34. Vidaillac, C.; Guillon, J.; Arpin, C.; Forfar-Bares, I.; Ba, B. B.; Grellet, J.; Moreau, S.; Caignard, D. H.; Jarry, C.; Quentin, C. Antimicrob. Agents Chemother. 2007, 51, 831.

https://doi.org/10.1128/AAC.01306-05

35. Sachs, G.; Shin, J. M.; Vagin, O.; Lambrecht, N.; Yakubov, I.; Munson, K. J. Clin. Gastroenterol. 2007, 41, S226. https://doi.org/10.1097/MCG.0b013e31803233b7

36. Wen, X.; El Bakali, J.; Deprez-Poulain, R.; Deprez, B. Tetrahedron Lett. 2012, 53, 2440. https://doi.org/10.1016/j.tetlet.2012.03.007

37. Hein, D.; Alheim, R. J.; Leavitt, J. J. Am. Chem. Soc. 1957, 79, 427. https://doi.org/10.1021/ja01559a053

38. Phillips, M. A. J. Chem. Soc. 1928, 2393. https://doi.org/10.1039/JR9280002393

39. Rambabu, D.; Murthi, P. R. K.; Dulla, B.; Basaveswara Rao, M.; Pal, M. Synth. Commun. 2013, 43, 3083. https://doi.org/10.1080/00397911.2013.769605

40. Tandon, V. K.; Kumar, M. Tetrahedron Lett. 2004, 45, 4185. https://doi.org/10.1016/i.tetlet.2004.03.117

41. Kawashita, Y.; Nakamichi, N.; Kawabata, H.; Hayashi, M. Org. Lett. 2003, 5, 3713. https://doi.org/10.1021/ol035393w

42. Bahrami, K.; Khodaei, M. M.; Nejati, A. Green Chem. 2010, 12, 1237. 
https://doi.org/10.1039/c000047g

43. Mukhopadhyay, C.; Tapaswi, P. K. Catal. Commun. 2008, 9, 2392.

https://doi.org/10.1016/j.catcom.2008.06.002

44. Bahrami, K.; Khodaei, M. M.; Naali, F. J. Org. Chem. 2008, 73, 6835.

https://doi.org/10.1021/jo8010232

45. Zhang, C.; Zhang, L.; Jiao, N. Green Chem. 2012, 14, 3273.

https://doi.org/10.1039/c2gc36416f

46. Park, S.; Jung, J.; Cho, E. Eur. J. Org. Chem. 2014, 4148.

https://doi.org/10.1002/ejoc.201402141

47. Williams, T. P.; Howell, W. L. Invest. Ophthalmol. Vis. Sci. 1983, 24(3), 285-287.

48. Pautler, E. L.; Morita, M.; Beezley, D. Photochem. Photobiol. 1990, 51(5), 599-605.

https://doi.org/10.1111/j.1751-1097.1990.tb01972.x

49. Lougheed, T. Environmental Health Perspectives 2014, 122(3), A81.

https://doi.org/10.1289/ehp.122-A81 